\title{
Implementasi Pembelajaran Online Berbasis Project Based Learning untuk Meningkatkan Kemandirian Belajar Siswa
}

\author{
Wina Anjarsari ${ }^{1}$, Suchie ${ }^{2}$, Dudin Kamaludin ${ }^{3}$ \\ ${ }^{1,2,3}$ SDN Model Kabupaten Sukabumi \\ *winauna01@gmail.com
}

\begin{tabular}{|l|l|l|l|}
\hline Received : 14-08-2021 & Revised: 07-11-2021 & Accepted: 08-11-2021 & Published: 21-12-2021 \\
\hline
\end{tabular}

\begin{abstract}
ABSTRAK
Penelitian ini dibuat dengan tujuan untuk menelaah kemandirian belajar siswa pada mata pelajaran matematika setelah menerapkan pembelajaran online berbasis proyek atau Project Based Learning dengan berbantuan aplikasi zoom meeting dan google classroom. Metode penelitian yang digunakan dalam penelitian ini adalah penelitian tindakan kelas (PTK). Populasi dalam penelitian ini adalah seluruh siswa kelas V SD Negeri Model Kab. Sukabumi pada tahun pelajaran 2020/2021. Peneliti mengambil sampel dari siswa kelas $\mathrm{V}$ yang berjumlah 28 orang siswa yang terdiri dari 12 orang siswa perempuan dan 16 orang siswa laki - laki. Data dalam penelitian ini diperoleh melalui instrumen yaitu kuisionerserta wawancara terhadap orang tua siswa. Hal ini dikarenakan pembelajaran yang dilaksanakan dengan sistem pembelajaran jarak jauh yakni dari rumah masing - masing. Hasil yang diperoleh dalam penelitian ini menunjukan bahwa pembelajaran online dengan berbasis proyek atau Project Based Learning dengan berbatuan aplikasi zoom meeting dan google classroom ini dapat meningkatkan kemandirian belajar siswa.
\end{abstract}

Kata Kunci : pembelajaran online, project based learning, kemandirian belajar, penelitian tindakan kelas

\section{ABSTRACT}

This study aims to examine the self-regulated learning of students in mathematics subject after implementing online learning based on Project Based Learning by using zoom meeting and google classroom. This research is classroom action research. The population in this study were all 5th grade students of SDN Model Kab. Sukabumi in the academic year 2020/2021. Researchers took samples from class $V$ which amounted to 28 people, there are 12 female students and 16 male students. The data were obtained through instruments, namely questionnaires and interviews with parent of students because learning was done from home. The result obtained are online learning based on Project Based Learning by using zoom meeting and google classroom can increase selfregulated learning of students.

Keyword : online learning, project based learning, self-regulated learning, classroom action research

\section{PENDAHULUAN}

Peradaban manusia yang berkembang secara linier mengikuti perkembangan ilmu pengetahuan dan teknologi. Secara berturut-turut masyarakat berkembang dari masyarakat primitif, masyarakat agraris, masyarakat industri, dan kemudian menjadi masyarakat informasi. Situasi abad 21 sering kali diidentikan dengan masyarakat informasi tersebut, yang ditandai oleh munculnya fenomena masyarakat digital. Sekarang ini, abad 21 dan 
masa mendatang, muncul apa yang disebut sebagai revolusi industri 4.0. Indonesia yang merupakan bagian dari masyarakat global, juga berkembang sebagaimana alur tersebut. Masyarakat Indonesia memang sudah menjadi bagian tidak terpisahkan dengan era digital. Setiap aktivitas manusia akan digerakkan melalui serangkaian teknologi digital. Transaksi perdagangan, komunikasi, semuanya digerakkan secara digital (Ngafifi, M. 2014). Teknologi digital juga membantu memudahkan dalam mencari informasi yang dibutuhkan untuk belajar.

Belajar merupakan sebuah proses untuk memperoleh suatu perubahan perilaku baik dalam bentuk pengetahuan, keterampilan maupun sikap dan nilai-nilai yang positif yang akan menjadi pengalaman untuk mendapatkan sejumlah hasil dari apa yang sudah dipelajari. Pendidikan merupakan faktor utama dalam pembentukan kepribadian manusia dan mengembangkan cara berfikir setiap individu agar menjadi manusia yang berguna bagi bangsa dan negara. Sekolah Dasar menjadi salah satu tonggak yang penting bagi keberlangsungan terbentuknya kepribadian dan pengetahuan seorang anak.

Kemampuan siswa diperoleh melalui proses belajar. Belajar yang saat ini dilaksanakan secara online karena adanya pandemi Covid-19 menuntut siswa untuk dapat belajar secara mandiri. Banyak keluhan dari orang tua siswa karena mereka lelah dengan pembelajaran yang dilaksanakan secara online ini. Rasa lelah tersebut karena orang tua merasa harus mengambil alih tugas guru dalam membelajarkan siswa di rumah juga membimbing anak-anak mereka dalam menyelesaikan tugas belajarnya. Terkadang karena alasan susah memberi penjelasan terkait tugas tersebut, maka orang tua siswa sendiri yang menyelesaikan tugas-tugas yang harusnya diselesaikan anak-anak mereka. Hal tersebut tidak akan terjadi apabila siswa dapat belajar secara mandiri.

Siswa yang memiliki kemandirian belajar tinggi cenderung belajar lebih baik, mampu memantau, mengevaluasi, dan mengatur belajarnya secara efektif; menghemat waktu dalam menyelesaikan tugasnya; mengatur belajar dan waktu secara efisien, dan memperoleh skor yang tinggi dalam sains (Hargis dalam Sumarmo 2004). Kemandirian dalam belajar sangat diperlukan untuk membentuk pribadi siswa yang percaya diri, bertanggung jawab dan mampu mengatasi masalah. Kemandirian belajar siswa akan mengantarkan siswa untuk belajar menganalisa dan mengembangkan pikiran kritis. Hanya saja hanya sebagian kecil dari siswa yang mampu belajar secara mandiri. Hal tersebut disebabkan pembelajaran online yang dilaksanakan oleh guru belum efektif.

Sejalan dengan masalah tersebut, perlu diupayakan suatu tindakan di kelas berupa strategi, model pembelajaran yang mampu meningkatkan kemandirian belajar 
siswa khususnya dalam pembelajaran online yang saat ini digunakan. Pembelajaran online ditandai dengan pemanfaatan teknogi informasi dan komunikasi untuk guru dan siswa berinteraksi. Terdapat banyak media berbasis aplikasi yang bisa digunakan untuk pembelajaran online. Pembelajaran online dapat dikombinasikan dengan model pembelajaran lainnya.

Model pembelajaran yang dapat meningkatkan kemandirian belajar siswa harus berpusat pada siswa. Siswa secara aktif melaksanakan pembelajaran serta menyelesaikan tugasnya dengan penuh rasa tanggung jawab. Untuk mewujudkan hal tersebut, guru dapat memberikan tugas proyek sederhana kepada siswa. Siswa dengan bimbingan guru dapat melakukan eksplorasi, penilaian, interpretasi, sintesis, dan informasi untuk menghasilkan karya yang menjadi tujuan proyek tersebut. Pembelajaran dengan proyek sebagai inti pembelajaran dinamakan pembelajaran berbasis proyek atau project-based learning (PjBL).

Project-based learning dapat dikombinasikan dengan pembelajaran online. Pembelajaran ini dinamakan pembelajaran online berbasis project-based learning. Pembelajaran tersebut menggunakan teknologi dan informasi sebagai media untuk berinteraksi juga proyek sebagai inti pembelajaran. Melalui pembelajaran online berbasis project-based learning ini diharapkan kemandirian siswa dalam belajar dapat lebih ditingkatkan.

Project-Based Learning adalah model pembelajaran yang menggunakan proyek sebagai inti pembelajaran. Siswa melakukan eksplorasi, penilaian, interpretasi, sintesis, dan informasi untuk menghasilkan berbagai bentuk hasil karya. Melalui pembelajaran online berbasis proyek ini diharapkan kemampuan dan kemandirian siswa dalam belajar dapat lebih ditingkatkan, sehingga dapat mengembangkan potensi yang dimilikinya.

Selanjutnya penelitian dari lis Solekhah (2018) dengan judul "Penerapan Model Pembelajaran Project Based Learning untuk Meningkatkan hasil Belajar Matematika Kelas II SD”, menjelaskan bahwa pembelajaran menggunakan project based learning dapat meningkatkan hasil belajar siswa. Terdapat juga pengaruh yang signifikan dalam penggunaan metode konvensional dengan model project based learning terhadap hasil belajar matematika. Namun terdapat perbedaan dan persamaan antara peneliti dengan penelitian sebelumnya. Persamaan peneliti dengan penelitian sebelumnya adalah sama - sama menerapkan model pembelajaran project based learning. Dengan menggunakan project based learning sebelumnya terbukti dapat meningkatkan hasil belajar siswa. Peneliti saat ini juga menerapkan project based learning, namun peneliti ingin sedikit berbeda yaitu dengan melaksanakan 
pembelajaran online berbatuan aplikasi zoom meeting dan google classroom sebagai upaya melaksanakan pembelajaran di masa pandemi COVID-19. Selain mengetahui hasil belajar siswa, peneliti juga berusaha menelaah kemandirian belajar siswa dengan penerapan project based learning tersebut.

Berangkat dari fenomena tersebut, maka peneliti tertarik untuk melaksanakan Penelitian Tindakan Kelas (PTK) dengan judul : "Implementasi Pembelajaran Online Berbasis Project Based Learning untuk Meningkatkan Kemandirian Belajar Siswa"

\section{METODE PENELITIAN}

Jenis Penelitian yang dilakukan adalah penelitian tindakan kelas (classroom action reseach). Populasi dan Sampel Populasi dalam penelitian ini adalah seluruh siswa kelas V SDN Model Kabupaten Sukabumi yang terdiri dari 28 orang.

Prosedur Penelitian Penelitian tindakan kelas dilakukan dengan beberapa tahapan/siklus. Model pembelajaran yang digunakan adalah pembelajaran online berbasis project-based learning.

1. Perencanaan (Planning).

Pada tahap ini dirumuskan strategi pembelajaran Project-based learning yaitu menyusun silabus, materi dan proyek yang akan dilakukan oleh siswa. Materi yang dipilih yaitu penyajian data. Adapun tugas proyek yang diberikan pada siswa berupa tugas individu, membuat laporan yang kemudian disajikan dalam bentuk tabel maupun diagram dan mempresentasikannya.

2. Pelaksanaan (Acting)

Tahap ini adalah menerapkan pembelajaran online berbasis project-based learning di dalam kelas melalui aplikasi zoom meeting. Pada pertemuan pertama di setiap siklus, siswa diajak untuk menyimak video dan handout materi yang dikirimkan di google classroom, sebagai feedback siswa diminta untuk bertanya di kolom komentar, dimana pertanyaan tersebut akan dibahas dan diperkuat dengan materi pada pertemuan kedua.

3. Pengamatan (Observing)

Dalam tahap ini peneliti bersama tim melakukan pengamatan terhadap kegiatan mahasiswa selama proses pembelajaran online berlangsung, baik tentang sikap maupun tingkah laku selama pembelajaran.

4. Refleksi (Reflecting)

Tahap ini merupakan kegiatan menganalisis dan menyimpulkan dari hasil pengamatan 
selama proses pembelajaran berlangsung, untuk mengetahui kemajuan hasil belajar siswa berdasarkan tugas proyek yang diberikan secara individu. Hasil belajar yang diperoleh siswa akan dibandingkan dengan kriteria ketuntasan belajar yang dibuat.

Penelitian ini direncanakan dua siklus, dalam satu siklus terdapat dua kali pertemuan yang dilaksanakan secara online melalui aplikasi google classroom dan zoom meeting. Pada setiap siklus akan dilakukan evaluasi dan observasi untuk melihat kemandirian belajar siswa.

Data diperoleh melalui intrumen yang dalam penelitian ini diantaranya adalah angket (kueisoner) untuk memperoleh data kemandirian belajar siswa setelah menerapkan pembelajaran online berbasis project-based learning; Observasi (pengamatan) yaitu untuk mengetahui situasi dan proses pelaksanaan kegiatan belajar mengajar ketika menggunakan aplikasi google classroom maupun zoom meeting; pedoman wawancara yaitu untuk memperoleh data kemandirian belajar siswa dari sudut pandang orang tua siswa.

\section{HASIL DAN PEMBAHASAN}

Penelitian dilakukan dalam 2 siklus, siklus 1 dilakukan dengan 2 kali pertemuan dan siklus ke 2 dengan 2 kali pertemuan.

\section{Tindakan pada Siklus I}

Pada siklus pertama materi yang disampaikan adalah penyajian data tunggal. Tahapan pelaksanaanya pada pertemuan pertama menyajikan materi berupa video dan handout yang dikirimkan melalui google classroom. Sebagai feedback dari siswa maka mereka diberikan kesempatan untuk bertanya di kolom komentar. Pemberian materi berupa video sangat bermanfaat agar siswa dapat belajar dengan mandiri dan menyesuaikan dengan gaya dan kecepatannya dalam memahami materi.Apabila siswa belum paham maka ia dapat memutar ulang rekaman video tersebut. Adapun handout diberikan sebagai pelengkap video. Aplikasi google classroom dipilih karena mudah mengoperasikannya serta terintegrasi dengan google drive. Hal ini akan memudahkan ketika akan mengambil ulang data baik itu materi maupun tugas-tugas siswa.

Pada pertemuan kedua di siklus ini dilaksanakan menggunakan zoom meeting. Dalam pertemuan ini membahas pertanyaan - pertanyaan yang telah disampaikan di kolom komentar dan untuk memperkuat pemahaman siswa atas materi sebelumnya serta menanyakan kemajuan tugas proyek yang diberikan sebelumnya. Aplikasi zoom meeting dipilih karena kebutuhan untuk berinteraksi dalam diskusi selayaknya pembelajaran dengan tatap muka.

Setelah melaksanakan pembelajaran sebanyak dua kali pertemuan siswa diminta 
mengisi kuisioner yang sudah berbentuk google-form berisi pernyataan tertutup mengenai kemandirian belajar. Setiap pernyataan dapat siswa pilih dengan selalu, sering, kadangkadang dan tidak pernah melaksanakan kegiatan yang mengarah pada kemandirian belajar. Dari hasil penelitian diperoleh data mayoritas siswa kadang-kadang merancang belajarnya sendiri sesuai dengan keperluan atau tujuan yang bersangkutan. Tidak ada siswa yang selalu memilih strategi dan melaksanakan rancangan belajarnya. Hanya sebagian kecil siswa yang selalu memantau kemajuan belajarnya sendiri, mengevaluasi hasil belajarnya dan dibandingkan dengan standar tertentu. Berdasarkan hasil ini perlu dilanjutkan pada siklus ke II.

\section{Tindakan pada Siklus II}

Pelaksanaan pembelajaran pada siklus II ini dimulai dengan membuat perencanaan tindakan. Materi yang diajarkan adalah interpretasi data yang merupakan materi lanjutan dari siklus sebelumnya. Siklus II dilaksanakan dua kali pertemuan. Pada pertemuan pertama pembelajaran melalui google classroom dengan strategi pembelajaran yang sama seperti siklus I. Pertemuan kedua juga menggunakan zoom meeting sama seperti pada siklus I. Setelah melaksanakan pembelajaran sebanyak dua kali pertemuan siswa diminta mengisi kuisioner yang sudah berbentuk google-form berisi pernyataan tertutup mengenai kemandirian belajar. Pada siklus II rata-rata siswa kemandirian belajar siswa meningkat. Untuk lebih jelasnya dapat dilihat dalam Tabel 1.

Tabel 1. Persentase Kemandirian Belajar Siswa dalam Siklus I dan Siklus II

\begin{tabular}{|c|c|c|c|c|c|c|c|c|c|}
\hline \multirow[t]{3}{*}{ No } & \multirow[t]{3}{*}{ Karakteristik } & \multicolumn{8}{|c|}{ Intensitas (\%) } \\
\hline & & \multicolumn{2}{|c|}{ Selalu } & \multicolumn{2}{|c|}{ Sering } & \multicolumn{2}{|c|}{ Kadang-kadang } & \multicolumn{2}{|c|}{ Tidak Pernah } \\
\hline & & I & II & I & II & I & II & I & II \\
\hline 1 & $\begin{array}{l}\text { Individu merancang } \\
\text { belajarnya sendiri } \\
\text { sesuai dengan } \\
\text { keperluan atau } \\
\text { tujuan individu } \\
\text { yang bersangkutan }\end{array}$ & 7,14 & 32,14 & 17,85 & 50 & 39,29 & 17,86 & 35,71 & 0 \\
\hline 2 & $\begin{array}{l}\text { Individu memilih } \\
\text { strategi dan } \\
\text { melaksanakan } \\
\text { rancangan } \\
\text { belajarnya }\end{array}$ & 0 & 28,57 & 25 & 50 & 39,29 & 21,43 & 35,71 & 0 \\
\hline 3 & $\begin{array}{l}\text { Individu memantau } \\
\text { kemajuan } \\
\text { belajarnya sendiri, } \\
\text { mengevaluasi hasil } \\
\text { belajarnya dan } \\
\text { dibandingkan } \\
\text { dengan standar } \\
\text { tertentu }\end{array}$ & 3,57 & 25 & 14,29 & 50 & 53,57 & 25 & 28,57 & 0 \\
\hline
\end{tabular}


Berdasarkan Tabel 1 tampak peningkatan dalam pilihan selalu dan sering pada setiap karakteristik. Selain itu juga terlihat penurunan intensitas dalam pilihan kadangkadang dan tidak pernah pada setiap karakteristik. Hal itu menunjukkan bahwa adanya peningkatan kemandirian belajar siswa dari siklus I ke siklus II. Bahkan pada siklus II tidak ada satu pun siswa yang memilih "tidak pernah" dalam setiap karakteristik yang mengarah pada kemandirian belajar. Artinya dalam diri seluruh siswa sudah muncul kemandirian belajar meskipun dengan intensitas yang berbeda-beda. Berdasarkan hasil ini penelitian tindakan kelas ini diakhiri dengan dua siklus saja. Berakhirnya penelitian bukan berarti tidak perlu lagi upaya untuk meningkatkan kemandirian belajar.

Peneliti juga melakukan wawancara terhadap tiga orang tua siswa secara acak. Berdasarkan hasil pengamatan orang tua siswa selama di rumah, setelah pembelajaran dilaksanakan dengan pembelajaran online berbasis project-based learning tampak bahwa siswa lebih antusias ketika akan memulai pembelajaran, tidak perlu disuruh untuk memulai pembelajaran bahkan dalam menyelesaikan tugasnya tidak terlalu mengandalkan orang tua meskipun masih ada yang perlu bimbingan. Selain itu, penggunaan beragam aplikasi membuat siswa mahir dalam menggunakan gadget dan tentunya dapat lebih bermanfaat dibandingkan sebelumnya (Septian, Ramadhanty, Darhim, \& Prabawanto, 2021; Suryawan \& Permana, 2020).

Selain dapat meningkatkan kemandirian belajar, project-based learning juga dapat meningkatkan hasil belajar dan motivasi siswa (Inayah, 2017). Project-based learning dapat diimplementasikan di berbagai jenjang pendidikan baik itu tingkat sekolah dasar (SD) maupun perguruan tinggi (Septian \& Rizkiandi, 2017). Project based learning menekankan keterlibatan siswa mulai dari merencanakan, membuat rancangan, melaksanakan dan melaporkan hasil kegiatan berupa produk dan laporan pelaksanaannya. Siswa melakukan eksplorasi, penilaian, interpretasi, sintesis, dan informasi untuk menghasilkan berbagai bentuk hasil belajar. Melalui project based learning, proses inquiri dimulai dengan memunculkan pertanyaan mendasar tentang suatu topik permasalahan yang terjadi dalam kehidupan sehari - hari dan membimbing siswa dalam sebuah proyek yang sedang dikajinya secara kolaboratif dengan bebagai cara yang bermakna bagi dirinya (Septian, Darhim, \& Prabawanto, 2020). Hal ini akan menjadikan proses pembelajaran menjadi bermakna dan berharga bagi atensi dan usaha para siswa.

Dengan diterapkannya project based learning, hasil belajar yang didapatkan pada pembelajaran matematika dengan materi penyajian data di kelas V SDN Model Kab. 
Sukabumi mengalami peningkatan yang signifikan. Peningkatan yang terjadi pada siklus I belum memenuhi target indikator yang telah ditetapkan, yaitu $75 \%$ dari 28 siswa. Maka dilanjutkan pada siklus II. Pada siklus I perolehan rata - rata nilai yang pada awalnya adalah 65,87 . Setelah siklus II, perolehan nilai rata - rata siswa pada mata pelajaran matematika dengan materi penyajian data meningkat menjadi 85,26. Hal ini membuktikan bahwa pembelajaran online berbasis project based learning, selain dapat meningkatkan kemandirian belajar siswa juga dapat meningkatkan hasil belajar dalam mata pelajaran matematika.

\section{KESIMPULAN}

Impelmentasi pembelajaran online berbasis project-based learning dapat meningkatkan kemandirian belajar siswa kelas V SDN Model Kab. Sukabumi tahun pelajaran 2020/2021.

\section{REFERENSI}

Admin. Metode pembelajaran ber-basis proyek (project based learning). [Online]. Tersedia : http //digilib.sunan-ampel. ac.id/files/disk1/151/hubptain-gdl- ellyik asus-7509-3-babii.pdf [15 Desember 2019]

Arikunto, S, Suhardjono dan Supardi. (2008) Penelitian tindakan kelas. Jakarta: Bumi Aksara

Asmani, Jamal Ma'mur. 2011. 7 Tips Aplikasi PAKEM (Pembelajaran Aktif, Kreatif, Efektif dan Menyenangkan). Yogyakarta: DIVA Press.

Aqib, Zaenal dkk. 2010. Penelitian Tindakan Kelas untuk Guru SD, SLB, dan TK. Bandung: Yrama Widya.

Bulqini, Apiet. (2019). Penerapan Model Pembelajaran Berbasis Proyek Pada Materi Penyajian Data Statistika Dalam Upaya meningkatkan Prestasi Belajar Siswa SMP. [Online]. Tersedia : https://jurnal.unsil.ac.id [10 Juli 2021]

Fikri. (2010). Penelitian tindakan kelas (classroom action research). [Online]. Tersedia : http//pakguruonline.pendidikan.net/ [15 Desember 2019]

Dimyati dan Mudjiono. (2005). Belajar dan pembelajaran. Jakarta: PT Rineka Cipta

Inayah, S.(2017). Implementasi Permbelajaran Berbasis Proyek untuk Meningkatkan Motivasi dan Hasil Belajar Mata Kuliah Strategi Belajar Mengajar. Jurnal Kependidikan, XVIII(1), 83-91.

Kennedi, Jhon. dkk. (2018). Desain pembelajaran penyajian data dengan model project based learning di kelas VII SMP. [Online]. Tersedia : callforpapers.uksw.edu/index.php/semsains/fsm2018/schedConf/presentations [10 Juli 2021]

Kementrian Pendidikan dan Kebudayaan. (2014). Materi Pelatihan Guru Implementasi Kurikulum 2013. Jakarta : Badan Pengembangan SDM Pendidikan dan Kebudayaan dan Penjaminan Mutu Pendidikan.

Maizon, H. (2010). Pembelajaran Quantum Untuk Meningkatkan Kemampuan Pemahaman Matematika dan Motivasi Siswa. Tesis SPs UPI Bandung: Tidak Diterbitkan 
Moursund, D., Bielefeldt, T., Ricketts, R., \& Underwood, S. (1997). Effect Practice:Computer Technology in Education. Eugene, OR: ISTE.

Septian, A., Darhim, \& Prabawanto, S. (2020). Mathematical representation ability through geogebra-assisted project- based learning models. Journal of Physics: Conference Series, 1657(1), 012019. https://doi.org/10.1088/1742-6596/1657/1/012019

Septian, A., Ramadhanty, C. L., Darhim, D., \& Prabawanto, S. (2021). Mathematical problem solving ability and student interest in learning using google classroom. Prosiding International Conference on Education of Suryakancana, 1(1), 155-161.

Septian, A., \& Rizkiandi, R. (2017). Penerapan model problem based learning (PBL) terhadap peningkatan kemampuan berpikir kreatif matematis siswa. PRISMA, 6(1). https://doi.org/10.35194/jp.v6i1.22

Solekhah, lis. dkk. (2018). Penerapan model pembelajaran project based learning untuk meningkatkan hasil belajar matematika kelas II SD. [Online]. Tersedia : https://jurnal.fkip.uns.ac.id [10 Juli 2021]

Sudjana, N. (2010). Penilaian hasil proses belajar mengajar. Bandung: PT. Ramaja Rosda-karya.

Suryawan, I. P. P., \& Permana, D. (2020). Media pembelajaran online berbasis geogebra sebagai upaya meningkatkan pemahaman konsep matematika. Prisma, 9(1), 108. https://doi.org/10.35194/jp.v9i1.929

Sutawijaya, A \& Dahlan, J.A. (2011). Pembelajaran matematika. Jakarta: Universitas Terbuka.

Wahidmurni, dkk. (2010). Evaluasi pembelajaran: kompetensi dan praktik. Yogyakarta: Nuha Letera. 